\title{
Exposure to depleted uranium does not alter the co-expression of HER-2/neu and p53 in breast cancer patients
}

\author{
Mais M Al-Mumen, Asad A Al-Janabi, Alaa S Jumaa, Kaswer M Al-Toriahi and Akeel A Yasseen*
}

\begin{abstract}
Background: Amongst the extensive literature on immunohistochemical profile of breast cancer, very little is found on populations exposed to a potential risk factor such as depleted uranium. This study looked at the immunohistochemical expression of HER-2/neu (c-erbB2) and p53 in different histological types of breast cancer found in the middle Euphrates region of Iraq, where the population has been exposed to high levels of depleted uranium.

Findings: The present investigation was performed over a period starting from September 2008 to April 2009. Formalin-fixed, paraffin-embedded blocks from 70 patients with breast cancer (62 ductal and 8 lobular carcinoma) were included in this study. A group of 25 patients with fibroadenoma was included as a comparative group, and 20 samples of normal breast tissue sections were used as controls. Labeled streptavidin-biotin (LSAB+) complex method was employed for immunohistochemical detection of HER-2/neu and p53.

The detection rate of HER-2/neu and p53 immunohistochemical expression were $47.14 \%$ and $35.71 \%$ respectively in malignant tumors; expression was negative in the comparative and control groups $(p<0.05)$.

HER-2/neu immunostaining was significantly associated with histological type, tumor size, nodal involvement, and recurrence of breast carcinoma $(p<0.05)$, p53 immunostaining was significantly associated with tumor size, nodal involvement and recurrence of breast cancer $(p<0.05)$. There was greater immunoexpression of HER-2/neu in breast cancer in this population, compared with findings in other populations.

Both biomarkers were positively correlated with each other. Furthermore, all the cases that co-expressed both HER2/neu and p53 showed the most unfavorable biopathological profile.

Conclusion: P53 and HER-2/neu over-expression play an important role in pathogenesis of breast carcinoma. The findings indicate that in regions exposed to high levels of depleted uranium, although p53 and HER-2/neu overexpression are both high, correlation of their expression with age, grade, tumor size, recurrence and lymph node involvement is similar to studies that have been conducted on populations not exposed to depleted uranium. HER-2/neu expression in breast cancer was higher in this population, compared with results on nonexposed populations.
\end{abstract}

\section{Introduction}

Breast carcinoma constitutes around one quarter of all cancers, making it the most common cancer in females [1], it is a heterogeneous disease with high individual variability as far as response to treatment is concerned [2]. Despite the increasing incidence rates of breast cancer, the morbidity and mortality rates are beginning

\footnotetext{
* Correspondence: a.yasseen@hotmail.com

Department of Pathology and Forensic Medicine, Faculty of Medicine, Kufa, University, Kufa, P.O. Box 18, Iraq
}

to fall. This decrease may reflect improvements in methods of diagnosis and treatment [3]. Several molecular markers that are important in the clinical aspect of malignancies especially in breast cancer have been detected [4]. Biological markers capable of predicting responsiveness to therapy would be of great help to physicians aiming to select the most appropriate treatment for each patient [5]. HER2/neu and p53 (both genes map to chromosome 17) are known biomarkers of breast cancer. HER2/neu is a member of the epidermal
C Biomed Central

() 2011 Yasseen et al; licensee BioMed Central Ltd. This is an Open Access article distributed under the terms of the Creative Commons Attribution License (http://creativecommons.org/licenses/by/2.0), which permits unrestricted use, distribution, and reproduction in any medium, provided the original work is properly cited. 
growth factor receptor (EGFR) family. Activation of the HER2/neu gene results in synthesis of $185 \mathrm{kD}$ transmembrane protein, whose intracellular domain possesses tyrosine kinase activity and through phosphorylation induction leads to tumor cell proliferation [6]. HER2/ neu amplification or over- expression has been shown to be associated with higher grades of tumor and poorer prognosis [6,7]. P53 is involved in regulating cell proliferation, including apoptosis, and in promoting chromosomal stability. It has been demonstrated that some percentage of breast cancers with mutations in p53 tumor suppressor gene are associated with clinical aggressiveness [8-12]. The prognostic and predictive value of HER2 and p53 biomarkers has been the subject of many investigations $[10,11]$, though the significance of their expression in cancer prognosis requires further study.

With respect to hormone receptors status (estrogen (ER) and progesterone (PR)), Breast cancer is considered as a hormone - dependent cancer. In published literature, approximately $50 \%$ of tumors are ER+ PR+; $25 \%$ ER- PR-; $20 \% \mathrm{ER}+\mathrm{PR}-$ and $5 \%$ are ER-PR+ $[13,14]$. Indeed, the estrogen receptor (ER) and the progesterone receptor (PR) have been widely accepted as established parameter in the management of patients with primary breast cancer along with HER-2/neu and P53 status as prognostic markers. Her-2/neu shows over- expression in high grade cancer and displays lower responsiveness to hormone receptors modulators. Hormone receptors positivity also correlate with absence of p53 mutation [15] and inversely with the presence of epidermal growth factor receptor [16].

On the other hand, Uranium exposure risk has been assessed in terms of radiation exposure. Human exposure to DU can occur through various routes including inhalation of DU particles, ingestion of DU-contaminated drinking water, soil, food or penetration of the body by bullets or shrapnel. It has been estimated that that 371 tones of DU were deposited in Iraqi Soil during the Desert Storm alone [17]. Recent literature includes much experimental evidence of adverse effects of DU including: altered gene expression in vitro [18], DNA strand breakage [19], carcinogenic mutation of human bronchial tissue [20] and genomic instability of human osteoblasts $[21,22]$. DU also produces increased urinary mutagenicity using the Ames test in rats [23]. Indeed, exposure to radiation leads to mutations in components of signaling pathways that control cell growth. Ultimately, these changes drive tumorigenesis through the coordinated phosphorylation of proteins, cell-cycle progression and metabolism, and transcription factors that regulate the expression of genes involved in these processes $[24,25]$. The mutations that cause cancer is produced by complex interactions between environmental and inherited factors. It is unlikely that a single specific abnormality causes all breast cancer. Defective P53 tumor suppressor gene, could allow abnormal cells to proliferate, resulting ultimately in cancer. As many as $50 \%$ of all human tumors are associated with P53 mutations [26]. HER-2 is encoded by the erbB-2 gene, the human homologue of the rat proto-oncogen neu [27]. Damage to either type of genes (tumor - suppressor gene and proto-oncogene) due to exposure to environmental factors (e.g. DU) can results in uncontrolled division of cells. This uncontrolled division forms tumors.

The present study is the first to look at the co-expression of these biomarkers in breast tissue samples from Iraqi women of the middle Euphrates area where the population was exposed to high levels of depleted uranium following the Gulf War. The results of this work are compared to findings on co-expression of these biomarkers in studies on breast cancer from other parts of the world, where depleted uranium exposure is not a risk.

\section{Methods}

Approval for the study was granted by the Iraqi Ministry of Higher Education and Scientific Research Ethics Committee and followed the Tents of Declaration of Helsinki. The Authors wrote to the patients asking if they would be willing to donate their tissues for the project. Families of individuals were also contacted. The samples were taken from consenting individuals and their families.

Seventy specimens of formalin-fixed, paraffin embedded breast cancer tissue, collected from breast cancer patients over a period from September 2008 to April 2009 were included in this study. All cases were referred to Kufa School of Medicine Teaching Hospital for histopathological evaluation from different parts of the middle Euphrates region of Iraq. The age range of patients was 22 to 70 years, with a mean age of 46.9 years. A group of 25 patients with benign breast lesions (fibroadenoma) was included as a comparative group and 20 normal breast tissue sections were included as controls. Confirmation of histopathological diagnosis and grading of tumors were carried out after reviewing all slides before proceeding further to the immunohistochemical analysis. Tissue sections with a thickness of $4 \mu \mathrm{m}$ were taken from the formalin-fixed, paraffin embedded blocks for immunohistochemistry. Labeled streptavidin-biotin (LSAB+) method was employed for immunohistochemical detection of HER2/neu and p53 using Polyclonal Rabbit Anti- Human c-erbB-2 Oncoprotein, Code No. 0485, Dako Denmark A/S Produktionsvej 42 DK-2600 Glostrup and Monoclonal Mouse Anti-Human p53 Protein, Ready-To-Use, DAKO, Clone DO-7, Code N1581, Inc. 6392, CA 93013 USA. The intensity of HER-2/neu cell membrane stain was classified into score 0 (completely 
negative), score $1+$ (negative; just perceptible staining of the membrane in $>10 \%$ of the malignant cells), score $2+$ (moderate staining of the partial membrane in $>10 \%$ of the malignant cells) and score $3+$ (strong circumferential staining of the entire membrane creating a fish-net pattern in $>10 \%$ of the malignant cells) [11]. The intensity of p53 nuclear stain was classified into score 0 (negative), score $1+$ (weak or mild staining, with $5-10 \%$ tumor cells staining positive), score $2+$ (moderate staining with less than 25\% of tumor cells staining positive), score $3+$ (strong staining, with $25-$ $50 \%$ of tumor cells staining positive) and score $4+$ (highly strong staining with over $50 \%$ of tumor cells staining positive) [12]. All biopsies were classified into three grades: Grade I, Grade II and Grade III, according to the modified Bloom Richardson Grading System [28]. The results were statistically evaluated with a Chi-squared test (at a significant level of $\mathrm{p}<0.05$ ) and correlation-regression analysis (at a significance level of $R=0.3$ ) using SSPS software.

\section{Results}

HER-2/neu and p53 immunoexpressions were positive in $47.14 \%$ and $35.71 \%$ of breast cancer cases, respectively, and negative in all sections of the normal and benign breast tissues. The differences between these groups were statistically significant $(p<0.05)$ (Table 1$)$. HER-2/neu over-expression was detected in $51.61 \%$ of ductal carcinomas cases and in $12.5 \%$ of invasive lobular carcinoma. The difference was statistically significant $(p<0.05)$.

As grouped in Table 1, over- expression of HER-2/neu was detected in only $40.43 \%$ of those with pure invasive ductal carcinomas (Figure 1), in comparison with $77.68 \%$ of invasive ductal carcinoma with an in situ comedo component (DCIS), in 100\% of invasive ductal carcinoma with overlying Paget's disease and in $100 \%$ of purely DCIS (Figure 2) and that with overlying Paget's disease. The differences were statistically significant $(\mathrm{p}<0.05)$.

HER-2/neu overexpression was detected in $50 \%$ of both grade I and II (well-moderately differentiated breast cancer) as compared to $46.43 \%$ of Grade III (poorly differentiated breast cancer). Statistically, no significant difference exists $(\mathrm{p}>0.05)$. Furthermore, a positive HER-2/neu overexpression was detected in all $(100 \%)$ of the Tis size breast tumors, in $28.57 \%$ of $\mathrm{T} 1$ size, $34.21 \%$ of $\mathrm{T} 2,68.42 \%$ of $\mathrm{T} 3$ and in $50 \%$ of $\mathrm{T} 4$. Table 1 shows that there is a high detection rate of HER-2 overexpression in recurrent breast cancer in comparison with primary lesions (84.21\% versus 33.33\%) $(\mathrm{p}<0.05)$, and in the presence (positive) or absence (negative) of axillary lymph nodes $(\mathrm{p}<0.05)(65.52 \%$ versus $22.22 \%$ ), a detection rate showed no correlation with patients age.
In the present study, p53 immunoexpression was detected in $37.10 \%$ of the ductal carcinomas cases and in $25 \%$ of invasive lobular carcinoma only (Table 1). P53 Immunoexpression was also detected in $38.30 \%$ of those tumors with pure invasive ductal carcinomas (Figure 3), in $22.22 \%$ of invasive ductal carcinoma with an in situ comedo component (DCIS), in $50 \%$ of invasive ductal carcinoma with overlying Paget's disease, in 33.33\% for purely DCIS (Figure 4) and in 100\% of those with overlying Paget's disease, in all these cases the incidence is significantly different from that found in control ( $\mathrm{p}<$ 0.05). On the other hand, p53 immunoexpression was detected in $14.29 \%$ of both grade I and II (well-moderately differentiated breast cancer) as compared to $41.07 \%$ of Grade III (poorly differentiated breast cancer). It is obvious that p53 immunoexpression was highly correlated with the grade of tumor $(\mathrm{R}=0.9)$ though no statistical significant difference was found $(\mathrm{P}>0.05)$. A positive p53 immunoexpression was detected in 50\% of Tis size of tumor, in $28.57 \%$ of T1, in $15.79 \%$ of T2, in $73.68 \%$ of $\mathrm{T} 3$ and in $50 \%$ of $\mathrm{T} 4$ size of tumor. A higher detection rates of p53 immunoexpression was found in recurrent breast cancer patients compared with the primary lesions $(63.16 \%$ versus $25.49 \%)$ ( $p<0.05)$ and in the presence (Positive) or absence (negative) of auxiliary lymph nodes (58.62\% versus $25.93 \%$ ). Again, there was a high detection rate in both age groups but no correlation with age was found. Both biomarkers are positively correlated with each others with respect to most clinicopathological parameters $(R=0.9)$. The percentage of the cases coexpressing both tumor markers is $18.57 \%$ (Table 2). All these cases showed the worst biopathological profile. The cases that co-expressed both biomarkers were found in $19.35 \%$ of ductal carcinoma, in $21.43 \%$ of poorly differentiated (grade III) tumor, in $50 \%$ of T4 tumor size, in $43.49 \%$ of those with positive axillary lymph node and in $47.37 \%$ of those that showed recurrence tumors. Furthermore, the co-expression of both biomarkers was significantly correlated with tumor grade and decreasing patients age $(R>0.3)$ (Table 2).

\section{Discussion}

Depleted uranium levels were estimated to be around 320-800 tons in the aftermath of the first Gulf war in 1991 with further comparable levels occurring in 2003. Since the targets were always in heavily populated areas in the middle and south of Iraq, the extent of population exposure has been extensive [29]. It has not been possible to obtain accurate measures of exposure because of official restrictions and the current political situation. Whilst there is plenty of anecdotal evidence for increases in the incidence of malignancies, infertility and congenital malformations, there is a paucity of studies to investigate these conditions on Iraqi populations. This has been 
Table 1 Immunoexpression of HER-2/neu and p53 in relation to clinicopathological parameters of breast carcinoma

\begin{tabular}{|c|c|c|c|c|c|}
\hline \multirow[t]{2}{*}{ Parameters } & \multirow{2}{*}{$\begin{array}{l}\text { Total number } \\
\text { of patients } \\
\text { No. } \%\end{array}$} & \multicolumn{2}{|c|}{$\begin{array}{l}\text { HER-2 } \\
\text { overexpression }\end{array}$} & \multicolumn{2}{|c|}{$\begin{array}{l}\text { P53 } \\
\text { immunoexpression }\end{array}$} \\
\hline & & $\begin{array}{l}\text { Positive } \\
\text { No. } \%\end{array}$ & $\begin{array}{l}\text { Negative } \\
\text { No. } \%\end{array}$ & $\begin{array}{l}\text { Positive } \\
\text { No. } \%\end{array}$ & $\begin{array}{l}\text { Negative } \\
\text { No. } \%\end{array}$ \\
\hline \multicolumn{6}{|l|}{ Type of breast tissue } \\
\hline Normal & $20(17.39)$ & $0(0)$ & $20(100)$ & $0(0)$ & $20(100)$ \\
\hline Benign (fibroadenoma) & $25(21.74)$ & $0(0)$ & $25(100)$ & $0(0)$ & $25(100)$ \\
\hline \multirow[t]{2}{*}{ Malignant } & $70(60.87)$ & $33(47.14)$ & $37(52.86)$ & $25(35.71)$ & 45 (64.29) \\
\hline & $P<0.05$ & & & $P<0.05$ & \\
\hline \multicolumn{6}{|l|}{ Histological type } \\
\hline Lobular carcinomas & $8(11.43)$ & $1(12.50)$ & $7(87.50)$ & $2(25)$ & $6(75)$ \\
\hline \multirow[t]{2}{*}{ Ductal carcinomas including: } & $62(88.57)$ & $32(51.61)$ & $30(48.39)$ & $23(37.10)$ & $39(62.90)$ \\
\hline & $P<0.05$ & & & $P>0.05$ & \\
\hline Pure IDC & $47(67.14)$ & $19(40.43)$ & $28(59.57)$ & $18(38.30)$ & $29(61.70)$ \\
\hline$I D C+D C I S$ & $9(12.86)$ & $7(77.68)$ & $2(22.22)$ & $2(22.22)$ & 7 (77.78) \\
\hline IDC+ Paget's & $2(2.86)$ & $2(100)$ & $0(0)$ & $1(50)$ & $1(50)$ \\
\hline DCIS + Paget's & $1(1.44)$ & $1(100)$ & $0(0)$ & $1(100)$ & $0(0)$ \\
\hline \multirow[t]{2}{*}{ Pure DCIS } & $3(4.29)$ & $3(100)$ & $0(0)$ & $1(33.33)$ & $2(66.67)$ \\
\hline & $P<0.05$ & & & $P>0.05$ & \\
\hline \multicolumn{6}{|l|}{ Tumor grade } \\
\hline Well-moderately differentiated (I and II) & $14(20)$ & $7(50)$ & $7(50)$ & $2(14.29)$ & $12(85.71)$ \\
\hline \multirow[t]{2}{*}{ Poorly differentiated (III) } & $56(80)$ & $26(46.43)$ & $30(53.57)$ & $23(41.07)$ & $33(58.93)$ \\
\hline & $P>0.05, R>0.3$ & & & $P>0.05$ & $R>0.3$ \\
\hline \multicolumn{6}{|l|}{$\underline{\text { Tumor size }}$} \\
\hline Tis & $4(5.71)$ & $4(100)$ & $0(0)$ & $2(50)$ & $2(50)$ \\
\hline $\begin{array}{l}\mathrm{T} 1(\leq \\
2 \mathrm{~cm})\end{array}$ & $7(10)$ & $2(28.57)$ & $5(71.43)$ & $2(28.57)$ & $5(71.43)$ \\
\hline $\mathrm{T} 2(2>-5 \mathrm{~cm})$ & $38(54.29)$ & $13(34.21)$ & $25(65.79)$ & $6(15.79)$ & $32(84.21)$ \\
\hline $\mathrm{T} 3(>5 \mathrm{~cm})$ & $19(27.14)$ & $13(68.42)$ & $6(31.58)$ & $14(73.68)$ & $5(26.32)$ \\
\hline \multirow[t]{2}{*}{ T4 (any T+other) } & $2(2.86)$ & $1(50)$ & $1(50)$ & $1(50)$ & $1(50)$ \\
\hline & $P<0.05$ & $\mathrm{R}<0.3$ & & $P<0.05$ & $\mathrm{R}>0.3$ \\
\hline \multicolumn{6}{|l|}{ Axillary lymph nodes 1} \\
\hline Negative & $27(48.21)$ & $6(22.22)$ & $2(77.78)$ & 7 (25.93) & $20(74.07)$ \\
\hline \multirow[t]{2}{*}{ Positive } & $29(51.79)$ & $19(65.52)$ & $10(34.48)$ & $17(58.62)$ & $12(41.38)$ \\
\hline & $P<0.05$ & & & $P<0.05$ & \\
\hline \multicolumn{6}{|l|}{ Age of the patient } \\
\hline$<35$ years & $19(27.14)$ & $12(63.16)$ & $7(36.84)$ & $8(42.11)$ & $11(57.89)$ \\
\hline \multirow[t]{2}{*}{$>35$ years } & $51(72.86)$ & $21(41.18)$ & $30(58.82)$ & $17(33.33)$ & $34(66.67)$ \\
\hline & $P>0.05$ & & & $P>0.05$ & \\
\hline \multicolumn{6}{|l|}{ Tumor recurrence } \\
\hline Primary & $51(72.86)$ & $17(33.33)$ & $34(66.67)$ & $13(25.49)$ & $38(74.51)$ \\
\hline \multirow[t]{2}{*}{ Recurrent } & $19(27.14)$ & $16(84.21)$ & $3(15.79)$ & $12(63.16)$ & $7(36.84)$ \\
\hline & $P<0.05$ & & & $P<0.05$ & \\
\hline
\end{tabular}

partly because of difficulties in obtaining samples compounded by the destruction of laboratory facilities and the lack of scientific and medical personnel. This study is the first to study breast cancer in an Iraqi population that had been exposed to high levels of depleted uranium and examine how the immunoexpression of HER-/neu and p53 compared with tumor grade and size.
In the present investigation the percentage of immunoexpression in malignant breast lesions ranges from $12.5 \%$ to $100 \%$ for HER-2/neu and from $22.22 \%-100 \%$ for $\mathrm{p} 53$. This study has found that HER-2/neu was overexpressed in $47.14 \%$ out of 70 breast cancer cases, a result that is higher than those reported elsewhere [30-32]. This may reflect the variant genetic make-up in 


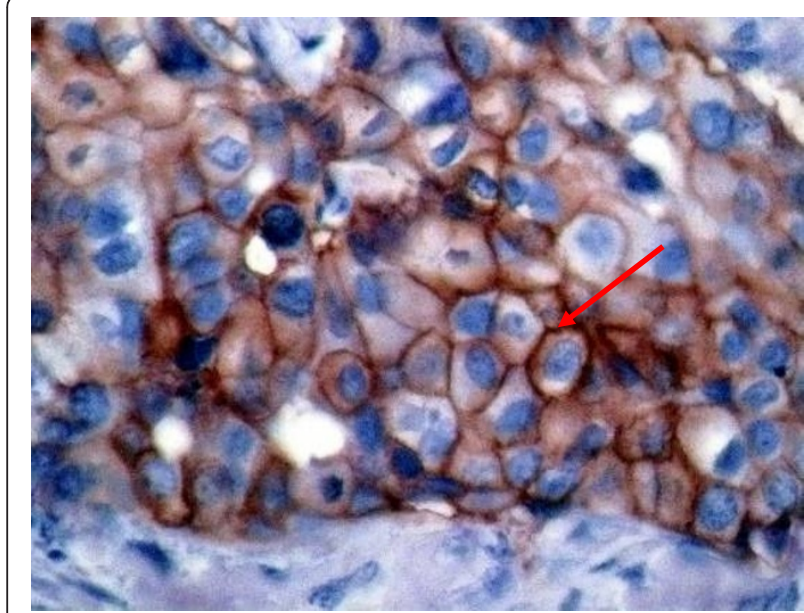

Figure 1 Invasive ductal carcinoma, showing strong membranous staining of Her2/neu, score 2+ (arrowed) (40x).

different ethnic groups or may be an effect of environmental damaging agents.

Furthermore, previous work that had been carried out in the same area showed relatively higher HER-2/neu over- expression (67.8\%) compared to the present investigation, though there was no significant difference was found between the two studies, the differences between the two can possibly be attributed to either the differences in the sample sizes, the period of samples collection or the sensitivity of the kit that had been used [33].

The immunoexpression of HER-2/neu in ductal carcinomas was significantly greater than that in infiltrating lobular carcinomas. The rate of expression of this biological marker was similar in both Paget cells and in the underlying intraductal and/or ductal carcinoma cells.

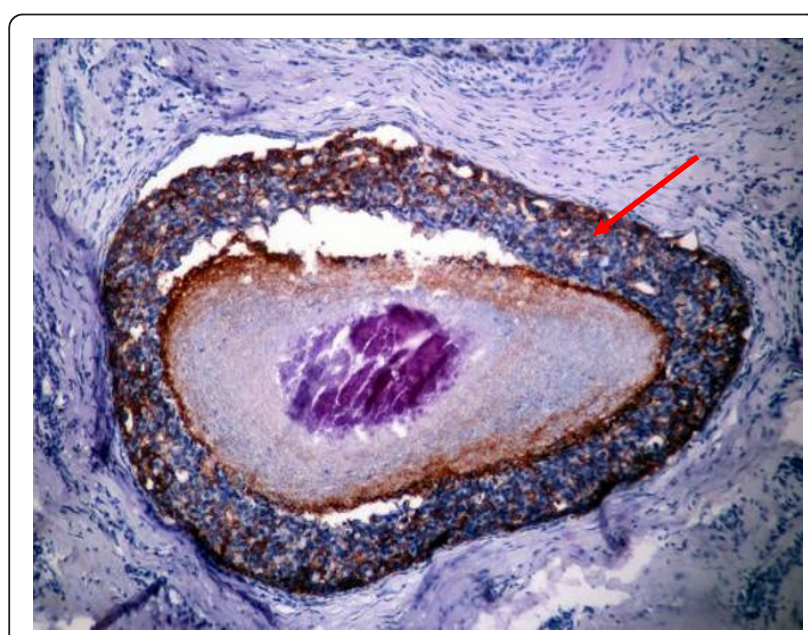

Figure 2 In situ ductal carcinoma of comedo type, showing strong membranous staining of Her2/neu, score 2+ (arrowed) (10x).

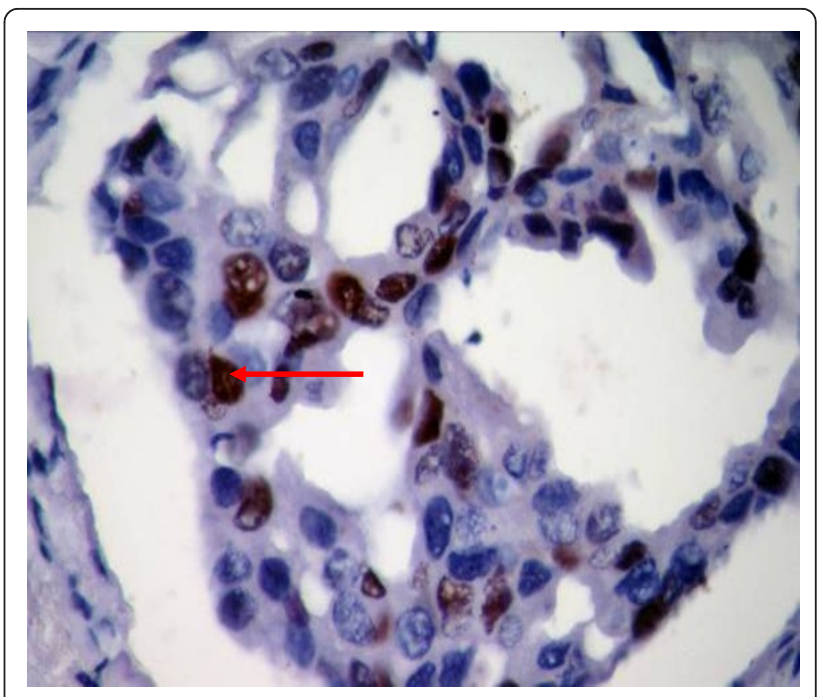

Figure 3 Invasive ductal carcinoma showing strong nuclear staining of P53, score 2+ (arrowed) (40X).

The current study showed that $100 \%$ of pure DCIS and $77.78 \%$ of DCIS with invasive component were HER2/neu positive. These results are consistent with previous findings that indicated a role of HER-2/neu in initiation rather than in progression of ductal carcinomas and suggested that this biomarker decreases as individual tumor cells evolve from in situ to increasingly invasive lesions [32]. HER-2/neu overexpression was seen in all cases which showed either invasive ductal carcinoma with Paget's disease or ductal carcinoma in situ with overlying Paget's disease components.

The proportions of purely invasive ductal carcinomas, purely DCIS and DCIS with invasive component that

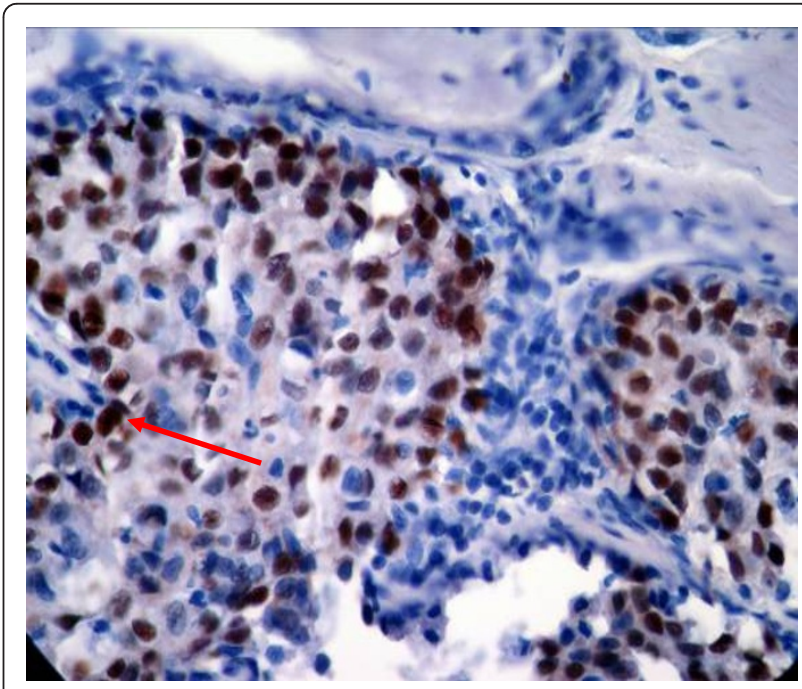

Figure 4 In situ ductal carcinoma showing strong nuclear staining of P53, score 3+ (arrowed) (20X). 
Table 2 Coexpression of HER-2/neu and p53 in relation to clinicopathological parameters of breast carcinoma

\begin{tabular}{|c|c|c|c|c|c|}
\hline Parameters & $\begin{array}{l}\text { Both } H E R-2 / \text { neu and } \\
\text { p53 positive }\end{array}$ & $\begin{array}{l}\text { Only HER-2/neu } \\
\text { positive }\end{array}$ & $\begin{array}{l}\text { Only p53 } \\
\text { positive }\end{array}$ & $\begin{array}{l}\text { both HER-2/neu and } \\
\text { p53 negative }\end{array}$ & Total \\
\hline \multicolumn{6}{|l|}{ Histological type } \\
\hline Ductal Carcinoma & $\begin{array}{l}12 \\
(19.35 \%)\end{array}$ & $\begin{array}{l}20 \\
(32.25 \%)\end{array}$ & $\begin{array}{l}11 \\
(17.45 \%)\end{array}$ & $\begin{array}{l}19 \\
(30.65 \%)\end{array}$ & $\begin{array}{l}62 \\
(88.57 \%)\end{array}$ \\
\hline \multirow[t]{2}{*}{ Lobular Carcinoma } & $\begin{array}{l}1 \\
(12.50 \%)\end{array}$ & $\begin{array}{l}0 \\
(0 \%)\end{array}$ & $\begin{array}{l}1 \\
(12.50 \%)\end{array}$ & $\begin{array}{l}6 \\
(75 \%)\end{array}$ & $\begin{array}{l}8 \\
(11.43 \%)\end{array}$ \\
\hline & $R>0.3$ & & & & \\
\hline \multicolumn{6}{|l|}{ Tumor grade } \\
\hline $\begin{array}{l}\text { Well-moderately differentiated } \\
\text { (I and II) }\end{array}$ & $\begin{array}{l}1 \\
(7.14 \%)\end{array}$ & $\begin{array}{l}6 \\
(42.86 \%)\end{array}$ & $\begin{array}{l}1 \\
(7.14 \%)\end{array}$ & $\begin{array}{l}6 \\
(42.86 \%)\end{array}$ & $\begin{array}{l}2 \\
(2.86 \%)\end{array}$ \\
\hline \multirow[t]{2}{*}{ Poorly differentiated (III) } & $\begin{array}{l}12 \\
(21.43 \%)\end{array}$ & $\begin{array}{l}14 \\
(25 \%)\end{array}$ & $\begin{array}{l}11 \\
(19.64 \%)\end{array}$ & $\begin{array}{l}19 \\
(33.93 \%)\end{array}$ & $\begin{array}{l}56 \\
(80 \%)\end{array}$ \\
\hline & $\mathrm{R}<0.3$ & & & & \\
\hline \multicolumn{6}{|l|}{$\underline{\text { Tumor size }}$} \\
\hline Tis & $\begin{array}{l}2 \\
(50 \%)\end{array}$ & $\begin{array}{l}2 \\
(50 \%)\end{array}$ & $\begin{array}{l}0 \\
(0 \%)\end{array}$ & $\begin{array}{l}0 \\
(0 \%)\end{array}$ & $\begin{array}{l}4 \\
(5.71 \%)\end{array}$ \\
\hline $\mathrm{T} 1$ & $\begin{array}{l}0 \\
(0 \%)\end{array}$ & $\begin{array}{l}2 \\
(28.57 \%)\end{array}$ & $\begin{array}{l}2 \\
(28.57 \%)\end{array}$ & $\begin{array}{l}3 \\
(42.86 \%)\end{array}$ & $\begin{array}{l}7 \\
(10 \%)\end{array}$ \\
\hline $\mathrm{T} 2$ & $\begin{array}{l}2 \\
(5.26 \%)\end{array}$ & $\begin{array}{l}11 \\
(28.94 \%)\end{array}$ & $\begin{array}{l}4 \\
(10.53 \%)\end{array}$ & $\begin{array}{l}21 \\
(55.27 \%)\end{array}$ & $\begin{array}{l}38 \\
(54.29 \%)\end{array}$ \\
\hline T3 & $\begin{array}{l}8 \\
(42.12 \%)\end{array}$ & $\begin{array}{l}5 \\
(26.31 \%)\end{array}$ & $\begin{array}{l}6 \\
(31.57 \%)\end{array}$ & $\begin{array}{l}0 \\
(0 \%)\end{array}$ & $\begin{array}{l}19 \\
(27.14 \%)\end{array}$ \\
\hline \multirow[t]{2}{*}{ T4 } & $\begin{array}{l}1 \\
(50 \%)\end{array}$ & $\begin{array}{l}0 \\
(0 \%)\end{array}$ & $\begin{array}{l}0 \\
(0 \%)\end{array}$ & $\begin{array}{l}1 \\
(50 \%)\end{array}$ & $\begin{array}{l}2 \\
(2.86 \%)\end{array}$ \\
\hline & $\mathrm{R}>0.3$ & & & & \\
\hline \multicolumn{6}{|l|}{ Axillary lymph nodes } \\
\hline $\begin{array}{l}\text { Node +ve } \\
\text { breast cancer }\end{array}$ & $\begin{array}{l}10 \\
(34.49 \%)\end{array}$ & $\begin{array}{l}9 \\
(31.03 \%)\end{array}$ & $\begin{array}{l}7 \\
(24.14 \%)\end{array}$ & $\begin{array}{l}3 \\
(10.34 \%)\end{array}$ & $\begin{array}{l}29 \\
(51.79 \%)\end{array}$ \\
\hline \multirow[t]{2}{*}{$\begin{array}{l}\text { Node-ve } \\
\text { breast cancer }\end{array}$} & $\begin{array}{l}2 \\
(7.41 \%)\end{array}$ & $\begin{array}{l}4 \\
(14.81 \%)\end{array}$ & $\begin{array}{l}5 \\
(18.52 \%)\end{array}$ & $\begin{array}{l}16 \\
(59.26 \%)\end{array}$ & $\begin{array}{l}27 \\
(48.21 \%)\end{array}$ \\
\hline & $\mathrm{R}<0.3$ & & & & \\
\hline \multicolumn{6}{|l|}{ Age of the patient } \\
\hline$<35$ years & $\begin{array}{l}8 \\
(4211 \%)\end{array}$ & $\begin{array}{l}4 \\
(21.05 \%)\end{array}$ & $\begin{array}{l}0 \\
(0 \%)\end{array}$ & $\begin{array}{l}7 \\
(36.84 \%)\end{array}$ & $\begin{array}{l}19 \\
(27.14 \%)\end{array}$ \\
\hline \multirow[t]{2}{*}{ > 35years } & $\begin{array}{l}5 \\
(9.81 \%)\end{array}$ & $\begin{array}{l}16 \\
(31.37 \%)\end{array}$ & $\begin{array}{l}12 \\
(23.53 \%)\end{array}$ & $\begin{array}{l}18 \\
(35.29 \%)\end{array}$ & $\begin{array}{l}51 \\
(72.86 \%)\end{array}$ \\
\hline & $R>-0.3$ & & & & \\
\hline \multicolumn{6}{|l|}{ Tumor recurrence } \\
\hline Primary & $\begin{array}{l}4 \\
(7.84 \%)\end{array}$ & $\begin{array}{l}13 \\
(25.49 \%)\end{array}$ & $\begin{array}{l}9 \\
(17.65 \%)\end{array}$ & $\begin{array}{l}25 \\
(49.02 \%)\end{array}$ & $\begin{array}{l}51 \\
(72.86 \%)\end{array}$ \\
\hline Recurrent & $\begin{array}{l}9 \\
(47.37 \%)\end{array}$ & $\begin{array}{l}7 \\
(36.84 \%)\end{array}$ & $\begin{array}{l}3 \\
(15.79 \%)\end{array}$ & $\begin{array}{l}0 \\
(0 \%)\end{array}$ & $\begin{array}{l}19 \\
(27.14 \%)\end{array}$ \\
\hline \multirow[t]{2}{*}{$\underline{\text { Total }}$} & $\begin{array}{l}13 \\
(18.57 \%)\end{array}$ & $\begin{array}{l}20 \\
(28.57 \%)\end{array}$ & $\begin{array}{l}12 \\
(17.14 \%)\end{array}$ & $\begin{array}{l}25 \\
(35.71 \%)\end{array}$ & $\begin{array}{l}70 \\
(100 \%)\end{array}$ \\
\hline & $\mathrm{R}>0.3$ & & & & \\
\hline
\end{tabular}

were p53 positive were similar to results found in other studies [34]. Paget's disease showed p53 expression in $50 \%$ of cases with an invasive component and in all cases which had an intra-ductal growth pattern.

Although a positive correlation between detection of HER-2/neu and p53 biomarkers with the grade of tumor was observed, no statistically significant difference was seen between these grades when compared for both biomarkers. This suggests that as the tumor advances other biological changes may occur that reduce the requirement for continued biomarker signaling. It is also possible that, when gene alterations occur in breast cancer, high proliferation rates are found irrespective of the presence of invasion and that other molecular alterations are involved in the development of breast cancer [35], Accordingly, the degree of differentiation does not contribute to the increase of the expression of both markers, though it may reflect the possible role of other pathways by which the 
tumor is advancing independently from the increase in signaling pathways of both HER2/neu and p53 genes. Thus, introducing a new line of treatment which include a genetic modulation of the signaling pathway may alter the prognosis of breast cancer patients which clearly requires further attention in future research and medical follow up. The detection rate of p53 increased with size of tumor and there was a significant difference among the various tumor sizes $(p<0.05)$. This observation is consistent with previous investigations [36-39].

There was a significantly higher HER-2/neu and p53 immunoexpression in recurrent breast cancer patients compared with the primary lesions $(\mathrm{p}<0.05)$. This is comparable with findings in previous studies [34-37] as is the strong correlation between HER-2/neu and p53 co-expression and grade, lymph node and tumor recurrence found in this study [40-43]. However, dissenting results that did not find a correlation between HER-2/ neu and p53 co-expression and other prognostic parameter have also been reported [44].

The present work confirms previous findings that combined alteration in the expression of HER-2/neu and $\mathrm{p} 53$, are linked to accelerated tumor progression and a poor prognosis [45]. Other studies, however, have suggested that tumor aggressiveness, associated with elevated expression of either protein, is not increased by the alteration of a second protein involved in the same signal transduction pathway [46].

\section{Conclusion}

In conclusion, the positive expression of these biomarkers is associated with biologically aggressive tumors and poor prognostic profile. Although the samples were taken from an area where the exposure to depleted uranium is a risk, the incidence of co-expression of both p53 and HER-2/neu markers does not differ from similar cancer samples in areas that have not been exposed to depleted uranium, though, the greater immunoexpression of Her-2/neu in breast cancer in this population with risk for DU exposure, compared with findings on other populations not at risk, requires further investigation as it may reflect the possible role of DU in the induction or acceleration of network signaling between different Her- 2 receptors. New lines of treatment which includes genetic modulation of the signaling pathway of both genes should be considered in patients' medical follow up. Unfortunately for DU, knowledge of the exposure time, dose absorbed, route, length of exposure and its health consequences on the Iraqi population is still lacking. This is chiefly due to restricted access of scientists required to conduct such study and should form the basis for future investigations.

\section{List of abbreviations}

LSAB+: Labeled Streptavidin-biotin; EGFR: epidermal growth factor receptor; ER: estrogen; PR: progesterone; DU: depleted uranium; DCIS: ductal carcinoma in situ.

\section{Acknowledgements}

We would like to express our sincere gratitude and appreciation to Professor P.G. McKenna, MRIA for reviewing the manuscript.

\section{Authors' contributions}

MMM carried out the immunohistochemical analysis and interpretation of the data, AAA participated in the design of the study, carried out the histopathological examination and helped to draft the manuscript, ASJ performed the statistical analysis, KST participated in the histopathological examination, AAY shared the design of the study and drafted the manuscript. All authors read and approved the final version of the manuscript.

\section{Competing interests}

The authors declare that they have no competing interests.

Received: 5 June 2010 Accepted: 29 March 2011

Published: 29 March 2011

\section{References}

1. Botha JL, Bray F, Sankila R, Parkin DM: Breast cancer incidence and mortality trends in 16 European countries. Eur J Cancer 2003, 39:1718-1729.

2. Harris J, Morrow M, Norton L: Malignant tumors of the breast. Principles and Practice of Oncology. 5 edition. Philadelphia. Pennsylvania. LippincottRaven; 1997, 1557-1616.

3. Chlebowski RT, Kuller LH, Prentice RL, Stefanick ML, Manson JE, Gass M, Aragaki AK, Ockene JK, Lane DS, Sarto GE, Rajkovic A, Schenken R, Hendrix SL, Ravdin PM, Rohan TE, Yasmeen S, Anderson G: Breast cancer after use of estrogen plus progestin in postmenopausal women. $N$ Engl J Med 2009, 360:573-587.

4. Wood WC, Muss HB, Solin LJ, Olopade Ol: Malignant tumors of the breast. Principles and Practice of Oncology. 7 edition. Lippincott Williams and Wilkins, Philadelphia; 2005, 1423-25.

5. Di Leo A, Larsimont D, Beauduin M, Cardoso F, Gancberg D, Rouas G: CMF or anthracycline based adjuvant chemotherapy for node-positive breast cancer patients. Proc Am Soc Clin Oncol 1999, 18:69.

6. Yarden Y: Biology of HER2 and its importance in breast cancer. Oncology 2001, 61:1-13.

7. Ivkovic-Kapicl T, Knezevic-Usaj S, Djilas-Ivanovic D, Panjkovic M: Correlation of HER-2/neu protein overexpression with other prognostic and predictive factors in invasive ductal breast cancer. In Vivo 2007, 21:673-678.

8. Osyka K, Ishioka C: TP53 mutations and molecular epidemiology. Gan To Kagaku Ryoho 2007, 34:683-689.

9. Yamashita H, Nishio M, Toyama T, Sugiura H, Zhang Z, Iwase S: Coexistence of HER2 over-expression and p53 protein accumulation is a strong prognostic molecular marker in breast cancer. Breast Cancer Res 2004, 6:24-30.

10. Chang K, Ding I, Kern FG, Willingham MC: Immunohistochemical analysis of p53 and HER-2/neu proteins in human tumors. J Histochem Cytochem 1991, 39:1281-1287.

11. Gardmark T, Wester K, Torre MD, Carlsson J, Malmström PU: Analysis of Her-2 $\backslash$ neu expression in primary bladder carcinoma and corresponding metastases. BJU International 2005, 95:982-986.

12. Apple SK, Hecht JR, Lewin DW, Jahromi SA, Grody WW, Nieberg RK: Immunohistochemical evaluation of K-ras, P53 and HER-2/neu expression in hyperplastic evidence for multistep carcinogenesis., dysplastic, and carcinomatous lesions of the pancreas. Human Pathology 1999, 30:123-129.

13. Vrbanec D, Petricevic B: Estrogen and Progesterone receptor status in primary breast cancer - a study of 11,273 patients from the year 1990 to 2002. Coll Antropol 2007, 31:535-540. 
14. Rhodes A, Jasani B, Balaton A, Barnes D, Miller K: Frequency of oestrogen and progesterone receptor positivity by immunohistochemical analysis in 7016 breast carcinomas: correlation with patients age, assay sensitivity, threshold value and mammographic screening. J Clin Patholo 2000, 53:688-696.

15. Caleffi M, Teague MW, Jensen RA, Vnencak-Jones $C L$, DuPont WD, Parl FF: P53 gene mutations and Steriod receptor status in breast cancer. Clinico pathologic correlations and prognostic assessment. Cancer 1994, 73:2147-2156.

16. Van Agthoven T, Timmermans M, Foekens JA, Doressers LC, HenzenLogmans SC: Differential expression of estrogen, progesterone and epidermal growth factor receptors in normal, benign and malignant human breast tissues using dual staining immunohistochemistry. Am J Pathol 1994, 144:1238-1246.

17. Briner WE: The evolution of Depleted Uranium as an environmental risk factor: Lessons from other metals. Int J Environ Res Public Health 2006, 3:129-135

18. Miller AC, Brooks K, Smith J, Page N: Effects of the military-relevant heavy metals, depleted uranium and heavy metals tungsten-alloy on gene expression in human liver carcinoma (HepG2). Mol Cell Biochem 2004, 255:247-256

19. Yazzie M, Gamble SL, Civitello ER, Stearns DM: Uranyl acetate causes DNA single strand breaks in vitro in the presence of ascorbate (vitamin C). Chem Res Toxicol 2003, 16:524-530.

20. Yang ZH, Fan BX, Lu Y, Cao ZS, Yu S, Fan FY, Zhu MX: Malignant transformation of human bronchial epithelial cell (BEAS-ZB) induced by depleted uranium. Ai Zheng 2002, 21:944-948.

21. Miller AC, Brooks K, Stewart M, Anderson B, Shi L, McClain D, Page N: Genomic instability in human osteoblast cells after exposure to depleted uranium: delayed lethality and micronuclei formation. J Environ Radioact 2003, 64:247-259.

22. Miller AC, Xu J, Stewart M, Brooks K, Hodge S, Shi L, Page N, McClain D: Observation of radiation-specific damage in human cells exposed to depleted uranium: dicentric frequency and neoplastic transformation as endpoints. Radiant Prot Dosimetery 2002, 99:273-278.

23. Miller AC, Fuciarelli AF, Jackson WE, Ejnik EJ, Emond C, Strocko S, Hogan J, Page N, Pellmar T: Urinary and serum mutagenicity studies with rats implanted with depleted uranium or tantalum pellets. Mutagenesis 1998, 13:643-648.

24. McCormick F: Signalling networks that cause cancer. Trends in Biochemical Sciences 1999, 24(12):M53-M56.

25. Luo J, Manning BD, Cantley LC: Targeting the PI3K-Akt pathway in human cancer: rationale and promise. Cancer Cell 2003, 4:257-262.

26. Vogelstein B, Lane D, Levine AJ: Surfing the P53 network. Nature 2000, 408:307-310.

27. Uchino S, Saito T, Inomata M, Osawa N, Chikuba K, Etoh K, Kobayashi M: Prognostic significance of the P53 mutation in esophageal cancer. Jpn J Clin Oncol 1996, 26:287-292.

28. Elston CW, Ellis IO: Pathological prognostic factors in breast cancer. I. The value of histological grade in breast cancer: experience from a large study with long-term follow-up. Histopathology 1991, 19:403-410.

29. Al-Azzawi SN: Depleted uranium radioactive contamination In Iraq: An overview. Global Research 2006, 1:4-8.

30. Salih F, Abdeen S: Pathobiological features of breast tumors in the State of Kuwait: a comprehensive analysis. J Carcinog 2007, 6:12.

31. Lee WY, Jin YT, Chang TW, Lin PW, Su IJ: Immunolocalization of BRCA1 protein in normal breast tissue and sporadic invasive ductal carcinoma: a correlation with other biological parameters. Histopathology 1999, 34:106-112.

32. Allred DC, Clark GM, Molina R, Tandon AK, Schnitt SJ, Gilchrist KW, Osbrne CK, Tormey DC, MCGuire WL: Over-expression of HER-2/neu and its relationship with other prognostic factors change during the progression of in situ to invasive breast cancer. Hum Pathol 1992, 23:974-979.

33. Al-Dujili EA, Al-Janabi AA, Pierscionek T, Yasseen AA: High prevalence of HER-2/neu overexpression in female breast cancer among an Iraqi population exposed to depleted uranium. J of carcinogenesis 2008, 7:8.

34. Poller DN, Hutchings CE, Galea M, Bell JA, Nicholson RA, Elston CW, Elston CW, Blamey EW, Elis IO: p53 protein expression in human breast carcinoma: relationship to expression of epidermal growth factor receptor, c-erbB-2 protein overexpression, and oestrogen receptor. $\mathrm{Br} \mathrm{J}$ Cancer 1992, 66:583-588

35. Nakopoulou LL, Alexiadou A, Theodoropoulos GE, Lazaris AC, Tzonou A, Keramopoulos A: Prognostic significance of the co-expression of p53 and c-erbB-2 proteins in breast cancer. J Pathol 1996, 179:31-38.

36. Carr JA, Havstad S, Zarbo RJ, Divine G, Mackowiak P, Velanovich V: The association of HER-2/neu amplification with breast cancer recurrence. Arch Surg 2000, 135:1469-1474.

37. Jukkola A, Bloigu R, Soini Y, Savolainen ER, Holli K, Blanco G: c-erbB-2 positivity is a factor for poor prognosis in breast cancer and poor response to hormonal or chemotherapy treatment in advanced disease. Eur J Cancer 2001, 37:347-354.

38. Salmon DJ, Godolphin W, Jones LA, Holt JA, Wong SG, Keith DE, Levin WJ, Stuart SG, Udove J, Ulrich A, et al: Studies of the HER-2/neu protooncogene in human breast cancer and ovarian cancer. Science 1989, 244:707-712.

39. Song HS, Do YR, Kang SH, Yong KJ, Kim YS: Prognostic significant of imunohistochemical expression of p53 gene in operable breast cancer. Cancer Res Treat 2006, 384:218-223.

40. Yamashita H, Nishio M, Toyama T, Sugiura H, Zhang Z, Kobayashi S, Iwase $\mathrm{H}$ : Coexistence of HER2 over-expression and $\mathrm{p} 53$ protein accumulation is a strong prognostic molecular marker in breast cancer. Breast Cancer Res 2004, 6:R24-R30.

41. Tsutsui S, Ohno S, Murakam S, Hachitanda Y, Oda S: Prognostic value of p53 protein expression in breast cancer, an immunohistochemical analysis of frozen sections in 514 Japanese women. Breast Cancer 2001, 8:194-201.

42. Iwaya K, Tsuda H, Hiraide H, Tamaki K, Tamakuma S, Fukutomi T, Mukai K, Hirohashi S: Nuclear p53 immunoreactions associated with poor prognosis of breast cancer. Jpn J Cancer Res 1991, 82:835-40.

43. Isola J, Visakorpi T, Holli K, Kallioniemi OP: Association of over-expression of tumor suppressor protein p53 with rapid cell proliferation and poor prognosis in node-negative breast cancer patients. J Natl Cancer Inst 1992, 84:1109-1114.

44. Lu X, Gu Y, Ding Y, Song W, Mao J, Tan J, Zaho H, Han X, Sun Y: Correlation of ER, PgR, HER-2/neu, p53, and VEGF with clinical characteristics and prognosis in Chinese women with invasive breast cancer. Breast J 2008, 14:308-310.

45. Beenken SW, Grizzle WE, Growe DR, Conner MG, Weiss HL, Sellers MT, Krontiras H, Urist MM, Bland Kl: Molecular Biomarkers for Breast Cancer Prognosis: Coexpression of c-erbB-2 and p53. Ann Surg 2001, 233:630-638.

46. Menard S, Casalini P, Pilotti S, Cascinelli N, Rilke F, Colnaghi MI: No additive impact on patient survival of the double alteration of p53 and c-erbB-2 in breast carcinomas. J Natl Cancer Inst 1996, 88:1002-1003.

doi:10.1186/1756-0500-4-87

Cite this article as: Al-Mumen et al:: Exposure to depleted uranium does not alter the co-expression of HER-2/neu and p53 in breast cancer patients. BMC Research Notes 2011 4:87.

\section{Submit your next manuscript to BioMed Central and take full advantage of:}

- Convenient online submission

- Thorough peer review

- No space constraints or color figure charges

- Immediate publication on acceptance

- Inclusion in PubMed, CAS, Scopus and Google Scholar

- Research which is freely available for redistribution

Submit your manuscript at www.biomedcentral.com/submit
C Biomed Central 